\title{
Deoiledjatropha seed cake is a useful nutrient for pullulan production
}

Anirban Roy Choudhury ${ }^{1 *}$, Nishat Sharma ${ }^{2}$ and GS Prasad ${ }^{3^{*}}$

\begin{abstract}
Background: Ever increasing demand for fossil fuels is a major factor for rapid depletion of these non-renewable energy resources, which has enhanced the interest of finding out alternative sources of energy. In recent years jatropha seed oil has been used extensively for production of bio-diesel and has shown significant potential to replace petroleum fuels at least partially. De-oiled jatropha seed cake (DOJSC) which comprises of approximately 55 to $65 \%$ of the biomass is a byproduct of bio-diesel industry. DOJSC contains toxic components like phorbol esters which restricts its utilization as animal feed. Thus along with the enhancement of biodiesel production from jatropha, there is an associated problem of handling this toxic byproduct. Utilization of DOJSC as a feed stock for production of biochemicals may be an attractive solution to the problem.

Pullulan is an industrially important polysaccharide with several potential applications in food, pharmaceuticals and cosmetic industries. However, the major bottleneck for commercial utilization of pullulan is its high cost. A cost effective process for pullulan production may be developed using DOJSC as sole nutrient source which will in turn also help in utilization of the byproduct of bio-diesel industry.
\end{abstract}

Results: In the present study, DOJSC has been used as a nutrient for production of pullulan, in place of conventional nutrients like yeast extract and peptone. Process optimization was done in shake flasks, and under optimized conditions (8\% DOJSC, 15\% dextrose, $28^{\circ} \mathrm{C}$ temperature, $200 \mathrm{rpm}, 5 \%$ inoculum, $6.0 \mathrm{pH}$ ) $83.98 \mathrm{~g} / \mathrm{L}$ pullulan was obtained. The process was further validated in a $5 \mathrm{~L}$ laboratory scale fermenter.

Conclusion: This is the first report of using DOJSC as nutrient for production of an exopolysaccharide. Successful use of DOJSC as nutrient will help in finding significant application of this toxic byproduct of biodiesel industry. This in turn also have a significant impact on cost reduction and may lead to development of a cost effective green technology for pullulan production.

Keywords: Jatropha, Value addition to waste, Aureobasidium pullulans, Fermentation, Exopolysaccharide, Pullulan

\section{Background}

Fossil fuels especially, fuels and commodities obtained from petroleum derived liquids play an important part in almost every aspect of our modern life. However, over exploitation of these natural resources to maintain modern amenities has caused negative ramifications on environmental as well as economical aspects of our life. Due to the limited nature of fossil fuels, their prices are

\footnotetext{
*Correspondence: anirban@imtech.res.in; prasad@imtech.res.in

'Biochemical Engineering Research \& Process Development Centre (BERPDC), CSIR-Institute of Microbial Technology (IMTECH), Council of Scientific and Industrial Research (CSIR), Sector - 39A, Chandigarh 160 036, India

${ }^{3}$ Microbial Type Culture Collection and Gene Bank (MTCC), CSIR-Institute of Microbial Technology (IMTECH), Council of Scientific and Industrial Research (CSIR), Sector - 39A, Chandigarh 160 036, India

Full list of author information is available at the end of the article
}

expected to increase more rapidly in the near future [1]. Therefore, to reduce the use of fossil fuels there is a compelling need to search alternative sources of energy. Production of fuels and chemicals from renewable biomass is becoming increasingly attractive and will be essential for our future and sustainability [2]. In recent years, Jatropha curcas L. has gained considerable attention as a potential source of biodiesel and many plantations of jatropha have been established in tropical and subtropical regions worldwide [3,4]. SWOT (Strength, Weakness, Opportunity and Threat) analysis carried out on the feasibility of jatropha biofuels suggests that to make it economically viable it is important to utilize by products produced during the biodiesel production from jatropha. De-oiled jatropha seed cake (DOJSC) produced 
during oil extraction is the major by product (55\%-65\% biomass) and contains several toxic substances which include phorbol esters, curicine etc. [5]. Presence of these toxic substances make de-oiled jatropha seed cake unsuitable as a feed for animal and poultry. Thus along with the development of biodiesel production from jatropha, there exists an inherent problem of handling this byproduct. Therefore, it is also important to find out suitable uses for the jatropha seed cake to sort out these problems. Studies have shown that this de-oiled jatropha seed cake is rich in different nutrients like minerals, amino acids etc. [6] suggesting that it may be possible to use this as a nutrient for production of valuable products.

Pullulan is an industrially important biopolymer having wide range of applications in food, pharma and cosmetic industries. In spite of several published reports on pullulan production via fermentation [7-9], cost of pullulan is high compared to other biopolymers like xanthan gum etc. [10]. Therefore, it is important to develop a suitable fermentation process which can make the product economical, either by increasing the yield or by lowering the cost of the media components. In most of the earlier published reports efforts were made to enhance the yield of pullulan production $[7-9,11]$. However, it is important to note that media components add significant cost to the production, and it may even reach up to $30 \%$ of the total production cost [12]. In some of the earlier reports urea, ammonium salts etc. as an alternative nitrogen source for pullulan production $[13,14]$. However, the yields reported in these cases were not good enough to make the process economical. Therefore, utilization of industrial by products for production of pullulan with desired yield may make the process economically viable.

Except a report describing utilization of soyabean pomace as nitrogen source for production of pullulan, in which the yield was very low [15], there are no other significant reports where agricultural residues were used as nutrient for production of pullulan. Recently, we have reported high pullulan production $(66.79 \mathrm{~g} / \mathrm{L})$ by an osmotolerant yeast Aureobasidium pullulans RBF 4A3 using glucose, yeast extract and peptone as nutrients[8]. In the present study we have examined potential of deoiled jatropha seed cake (DOJSC) as a nutrient to substitute costly nutrients like yeast extract and peptone for production of pullulan by Aureobasidium pullulans RBF-4A3. The process of pullulan production was optimized in shake flask and the overall pullulan production and yield obtained is high compared to earlier published reports $[16,17]$. This is the first report of pullulan production using de-oiled jatropha seed cake as nutrient. A process economic analysis has shown that use of DOJSC as nutrient can reduce the raw material cost considerably and this may lead to development of successful commercial process for pullulan production. Therefore, the outcome of the present study will not only help in waste minimization and value addition to the waste produced during bio-diesel production from jatropha, but also help in reduction of raw material cost for pullulan production.

\section{Results and discussions}

\section{Optimization of culture conditions}

The pullulan production process was optimized using single point optimization technique. Influences of different factors like DOJSC concentration in media, incubation temperature, agitation speed, inoculum size and initial $\mathrm{pH}$ of the media on pullulan production were examined.

\section{Effect of concentration of de-oiled jatropha seed cake in production media}

DOJSC is a rich source of protein (56.4-63.8\%) and also contain fibers (8.1-9.1\%) [18]. Although DOJSC is very rich in essential nutrients especially amino acids for growth of microbes, at higher concentrations it may be detrimental for growth and product formation. Hence it is important to find out optimum concentration of DOJSC for pullulan production. Shake flask fermentations were carried out by varying DOJSC concentration from $2 \%$ to $14 \%(\mathrm{w} / \mathrm{v})$ in the production media. Initially the pullulan production increased with increase in DOJSC concentration from $61.18 \mathrm{~g} / \mathrm{L}$ at $2 \%$ $(\mathrm{w} / \mathrm{v})$ to $82.57 \mathrm{~g} / \mathrm{L}$ at $8 \%(\mathrm{w} / \mathrm{v})$ concentration. However at concentration beyond $8 \%$ gradual reduction in pullulan production was observed and it went down to $69.21 \mathrm{~g} / \mathrm{L}$ when DOJSC was increased up to $14 \%$ DOJSC (Figure 1). This may be attributed to that fact that higher concentration of DOJSC has a negative impact on the metabolic activities of microbial cells, which ultimately affect the production of the exopolysaccharide.

\section{Effect of incubation temperature on pullulan production}

Incubation temperature is strain dependent and has significant influence on growth and production of pullulan during fermentation [19] suggesting the need to determine optimum temperature to maximize pullulan production. The incubation temperature was varied from $15^{\circ} \mathrm{C}$ to $30^{\circ} \mathrm{C}$ to examine the effect of the same on pullulan production. Optimum pullulan production was obtained at $28^{\circ} \mathrm{C}(82.91 \mathrm{~g} / \mathrm{L})$ and it was almost twice as compared to the production at $15^{\circ} \mathrm{C}$ (Figure $2 \mathrm{~A}$ ). However, as the temperature was increased to $30^{\circ} \mathrm{C}$ there was significant reduction in pullulan production (45.11 $\mathrm{g} / \mathrm{L})$. This observation is in agreement with the observations of Roukas and Biliaderis [20], but different from 


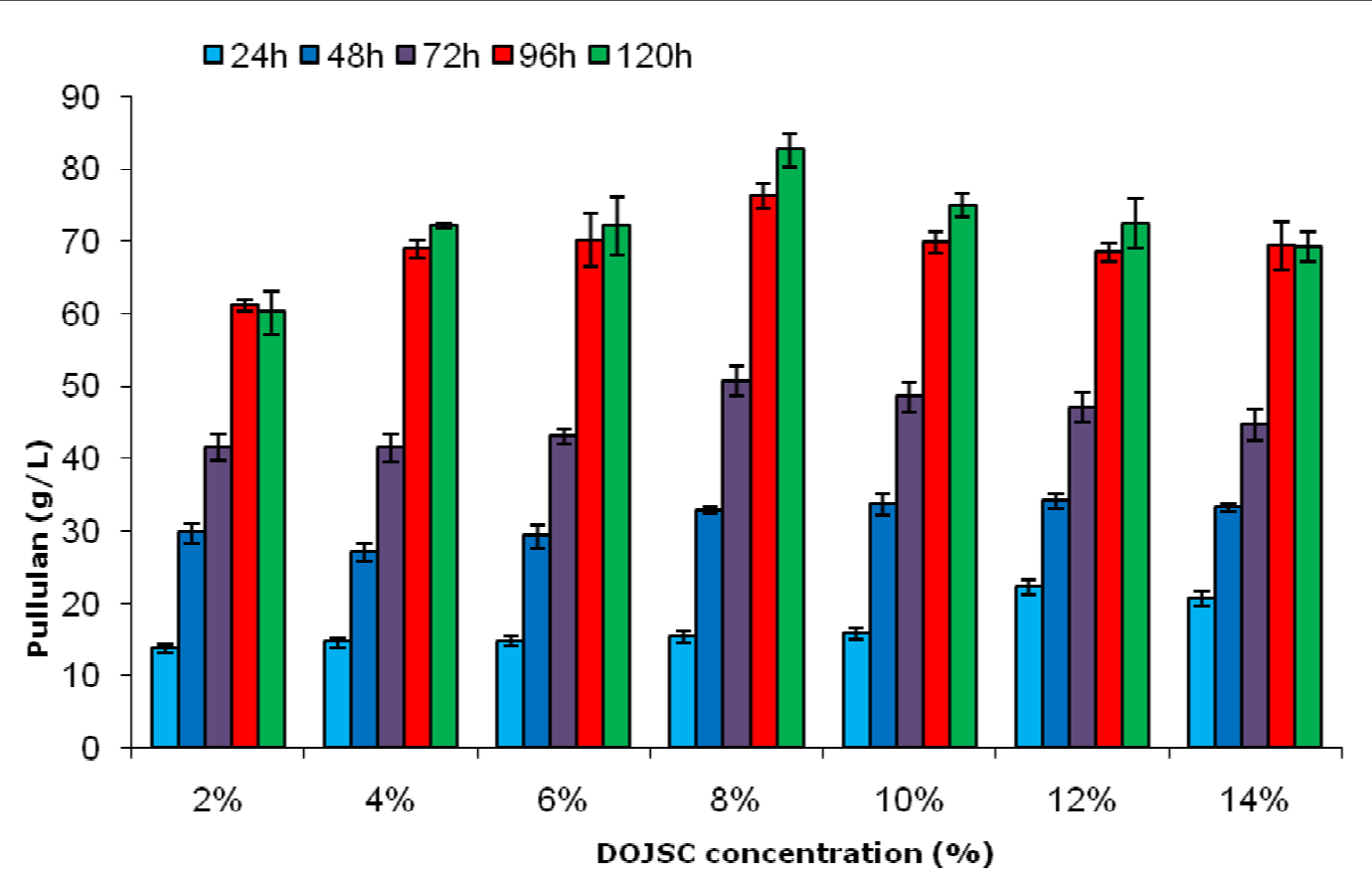

Figure 1: Effect of DOJSC concentartion on pullulan production by Aureobasidium pullulans RBF-4A3. DOJSC concentration was varied from $2 \%(\mathrm{w} / \mathrm{v})$ to $14 \%(\mathrm{w} / \mathrm{v})$ by using $2 \%(\mathrm{v} / \mathrm{v})$ inoculum size at 200 rpm.

Figure 1

other report which shows optimal pullulan production at $25^{\circ} \mathrm{C}$ [21]. This confirms the earlier observations that the temperature optimum for production of pullulan is strain specific and also often corresponds to the optimum temperature of growth of the microorganism used for production.

\section{Effect of agitation speed on pullulan production}

Agitation speed determines the level of mixing and homogeneity during fermentation and helps in maintenance of a concentration gradient between exterior and interior of the cells by continuous surface renewals. A steady concentration gradient ensures smooth and continuous transport of substrates, other nutrients and products across the cell wall. However, high shear is generated at higher agitation speeds may lead to cell damage and thus affect the growth and polymer production. Therefore, it is important to find out optimum condition of agitation to achieve higher level of production. In the present study, effect of agitation speed was examined at 5 different levels $(100,200$, $250,300,350 \mathrm{rpm}$ ). The results obtained clearly shows that agitation speed of 100 supported very little (17.37 $\mathrm{g} / \mathrm{L}$ ) pullulan production, indicating that it was too low for production. All other agitation speeds supported almost similar pullulan production up to 72 hours, after which $200 \mathrm{rpm}$ was found to be the best for pullulan production $(83.13 \mathrm{~g} / \mathrm{L})$ with increase in $\mathrm{rpm}$ beyond 200, there was a gradual decrease in pullulan production (Figure $2 \mathrm{~B}$ ).

\section{Effect of inoculum size on pullulan production}

Inoculum size has significant effect on the productivity in fermentation processes as it defines the initial microbial load in the fermentation system and thus controls duration of lag phase and subsequently production of the target metabolites. It has been observed that inoculum size has significant effect on the cell morphology and growth pattern of Aureobasidium pullulans, and change in morphology has significant effect on pullulan production [22]. In order to find out optimum inoculum size for pullulan production, its concentration was varied from $2 \%$ to $10 \%(\mathrm{v} / \mathrm{v})$. The results obtained show that pullulan production is low when $2 \%(\mathrm{v} / \mathrm{v})$ inoculum was used and increased to $83.46 \mathrm{~g} / \mathrm{L}$ pullulan was obtained at the end of 120 hours fermentation when 5\% $(\mathrm{v} / \mathrm{v})$ inoculum was used. Further increase of inoculum size up to $10 \%$ adversely affected pullulan production (Figure $3 \mathrm{~A})$ suggesting that $5 \%(\mathrm{v} / \mathrm{v})$ concentration is optimal for pullulan production. 


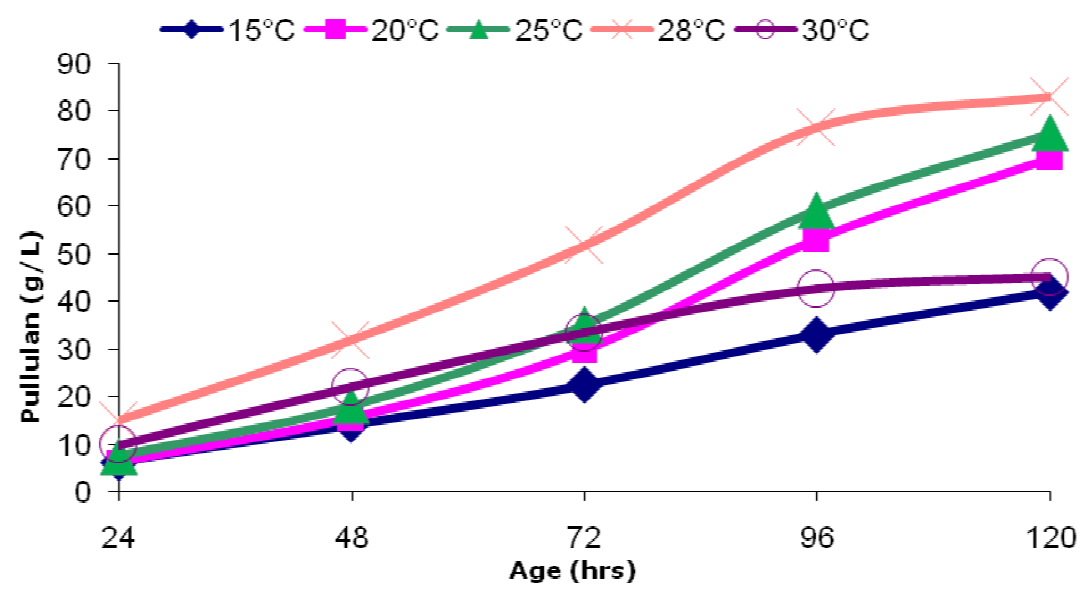

Figure 2A: Effect of incubation temperature on pullulan production by Aureobasidium pullulans RBF-4A3. The incubation temperature varied from $15^{\circ} \mathrm{C}$ to $30^{\circ} \mathrm{C}$. DOJSC maintained at $8 \%$ $(\mathrm{w} / \mathrm{v})$, inoculated with $5 \%(\mathrm{v} / \mathrm{v})$ inoculum size and incubated at $200 \mathrm{rpm}$.

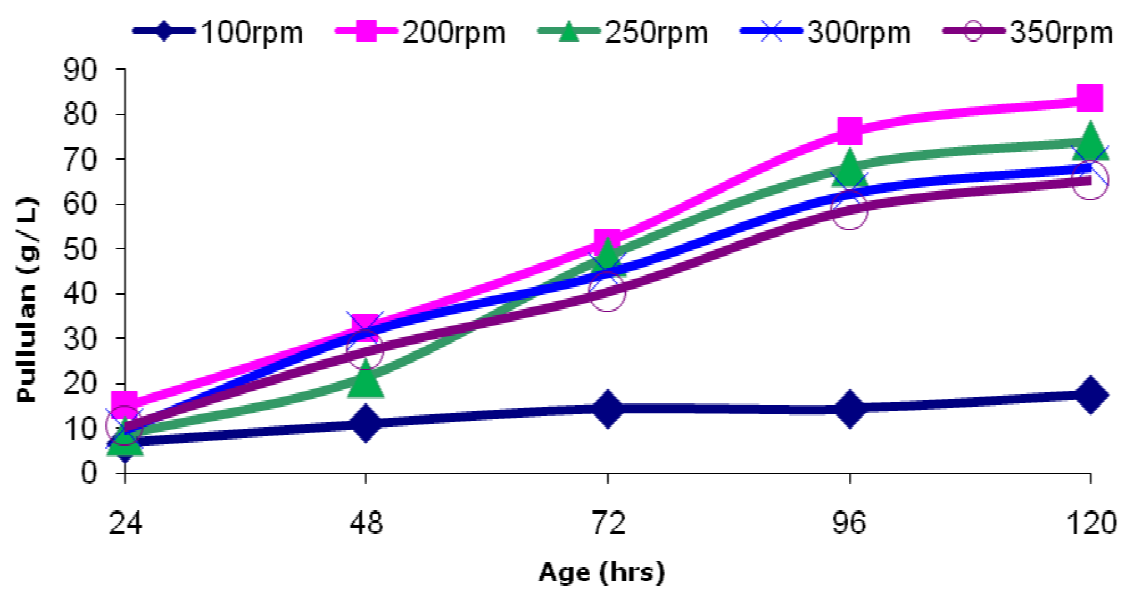

Figure 2B: Effect of agitation speed on pullulan production by Aureobasidium pullulans RBF-4A3. In this agitation speeds were varied from $100 \mathrm{rpm}$ to $350 \mathrm{rpm}$. The DOJSC was used at $8 \%(\mathrm{w} / \mathrm{v})$ concentration and the flasks were incubated at $28^{\circ} \mathrm{C}$.

Figure 2

Effect of initial $\mathrm{pH}$ on pullulan production

$\mathrm{pH}$ plays and important role in metabolic activities of microbial cells and it has been observed that cell morphology of Aureobasidium pullulans depends on the $\mathrm{pH}$ of the media which in turns affects the production of the polymer $[23,24]$. In present study the initial $\mathrm{pH}$ of the media was varied from 3.5 to 6.5 to understand its effect on pullulan production. Pullulan production was less at an initial pH of 3.5 and increases with increase in initial $\mathrm{pH}$ up to 6.0 (Figure $3 \mathrm{~B}$ ) and 


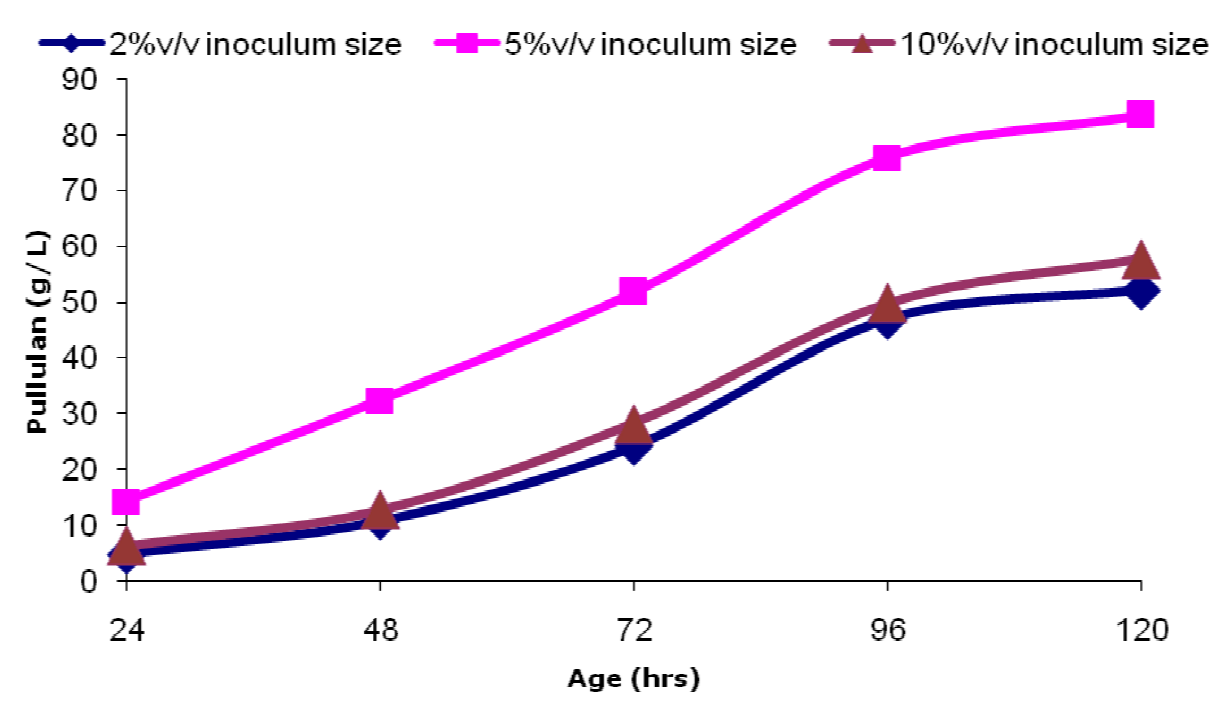

Figure 3A: Effect of inoculumn size on pullulan production by Aureobasidium pullulans RBF-4A3. In this case inoculumn size was varied from $2 \%(\mathrm{v} / \mathrm{v})$ to $10 \%(\mathrm{v} / \mathrm{v})$ and incubation was done at $28^{\circ} \mathrm{C}$ with media containing DOJSC $8 \%(w / v)$.

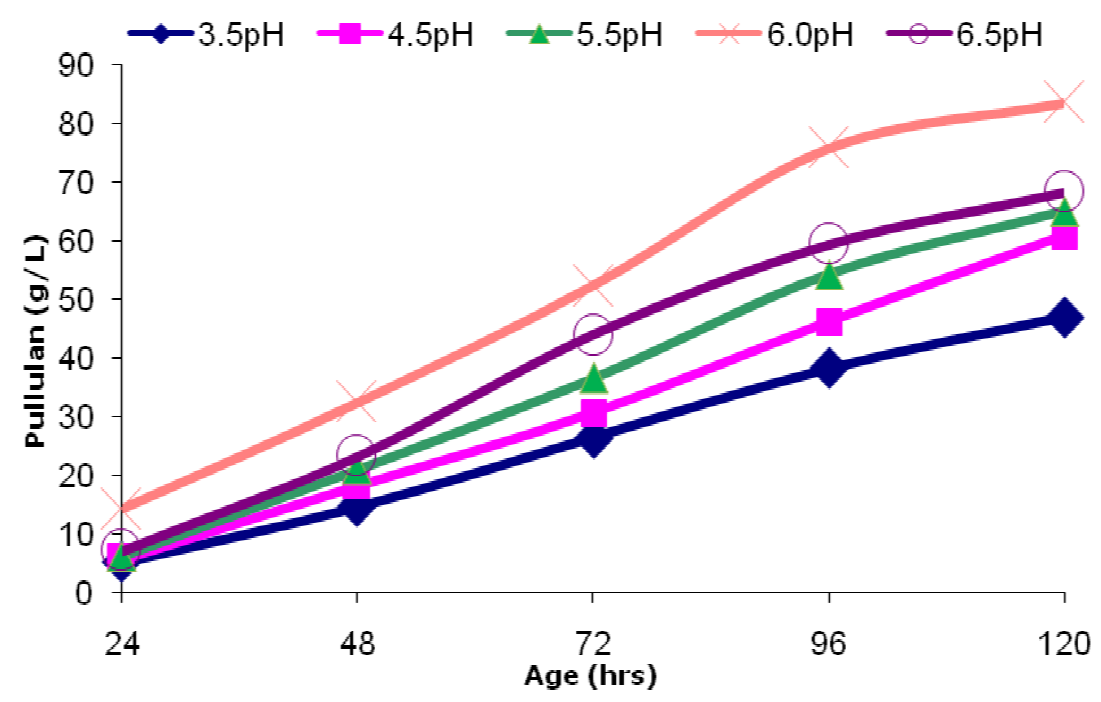

Figure $3 \mathrm{~B}$ Effect of initial $\mathrm{pH}$ on pullulan production by Aureobasidium pullulans RBF-4A3. Initial $\mathrm{pH}$ was varied from 3.5 to 6.5 and flasks were incubated with a media containing $8 \%$ DOJSC.

Figure 3

decreases at higher $\mathrm{pH}$ (6.5). It was observed that an initial $\mathrm{pH}$ of 6.0 is most suitable for the production of pullulan $(83.59 \mathrm{~g} / \mathrm{L})$. In earlier reports Roukas and Biliaderis [25] observed that maximum pullulan production at a $\mathrm{pH}$ of 6.5, whereas Auer and Seviour [26] reported maximum pullulan production at an initial $\mathrm{pH}$ of 7.5. The results obtained along with earlier published reports clearly indicate that the $\mathrm{pH}$ optima depend on the strain as well as on the substrate used for production of polymer. 
Validation of shake flask experiments in a laboratory scale fermenter

The optimized batch was run in a $5 \mathrm{~L}$ fermenter (New Brunswick Scientific, Bioflow 310) with 3.5 L working volume to validate the observations of shake flask experiments. The fermentation kinetics of the optimized batch (Figure 4) showed that the rate of polysaccharide production is directly proportional with consumption of carbon source. The $\mathrm{pH}$ of the medium increased during the process till 96 hours and $83.98 \mathrm{~g} / \mathrm{L}$ of pullulan was produced at the end of the batch. FT-IR data (Additional file 1: Figure S1) shows that the spectra obtained for standard pullulan (Sigma) and the pullulan produced using DOJSC as a nutrient are almost identical confirming the chemical structure of the polymer obtained via fermentation with DOJSC as nutrient is same as standard sigma pullulan. The overall results obtained indicate that the process optimized in the shake flask level may be scaled up easily to fermenter and it may lead to development of a successful and cost effective technology for pullulan production. It should also be noted that optimum production obtained in fermenter is significantly high as compared to earlier reports (Table 1). The yield obtained here is also significantly high as compared to earlier reports published and hence, may have significant impact on the production cost of the polymer.

\section{Process economics}

Cost analysis of ingredients used in fermentation process for production showed that major cost of the production of the polymer is associated with the cost of nitrogen sources used. DOJSC contains around 56-63\% protein and $8-9 \%$ fiber, and therefore, it can be used as a nutrient for replacing conventional nitrogen sources. As, the cost of DOJSC is much less as compared to conventional nitrogen sources, replacing the conventional nitrogen sources with DOJSC results in significant cost reduction. A process economics analysis suggest that the use of de-oiled jatropha seed oil cake can reduce the raw material cost by $94 \%$ as compared to conventional nitrogen sources like yeast extract and peptone (Table 2 ). This may be helpful in economical production of pullulan along with utilization of the DOJSC.

\section{Conclusion}

In the present study $83.98 \mathrm{~g} / \mathrm{L}$ pullulan was produced under optimized conditions using DOJSC as nutrient which is significantly higher compared to earlier

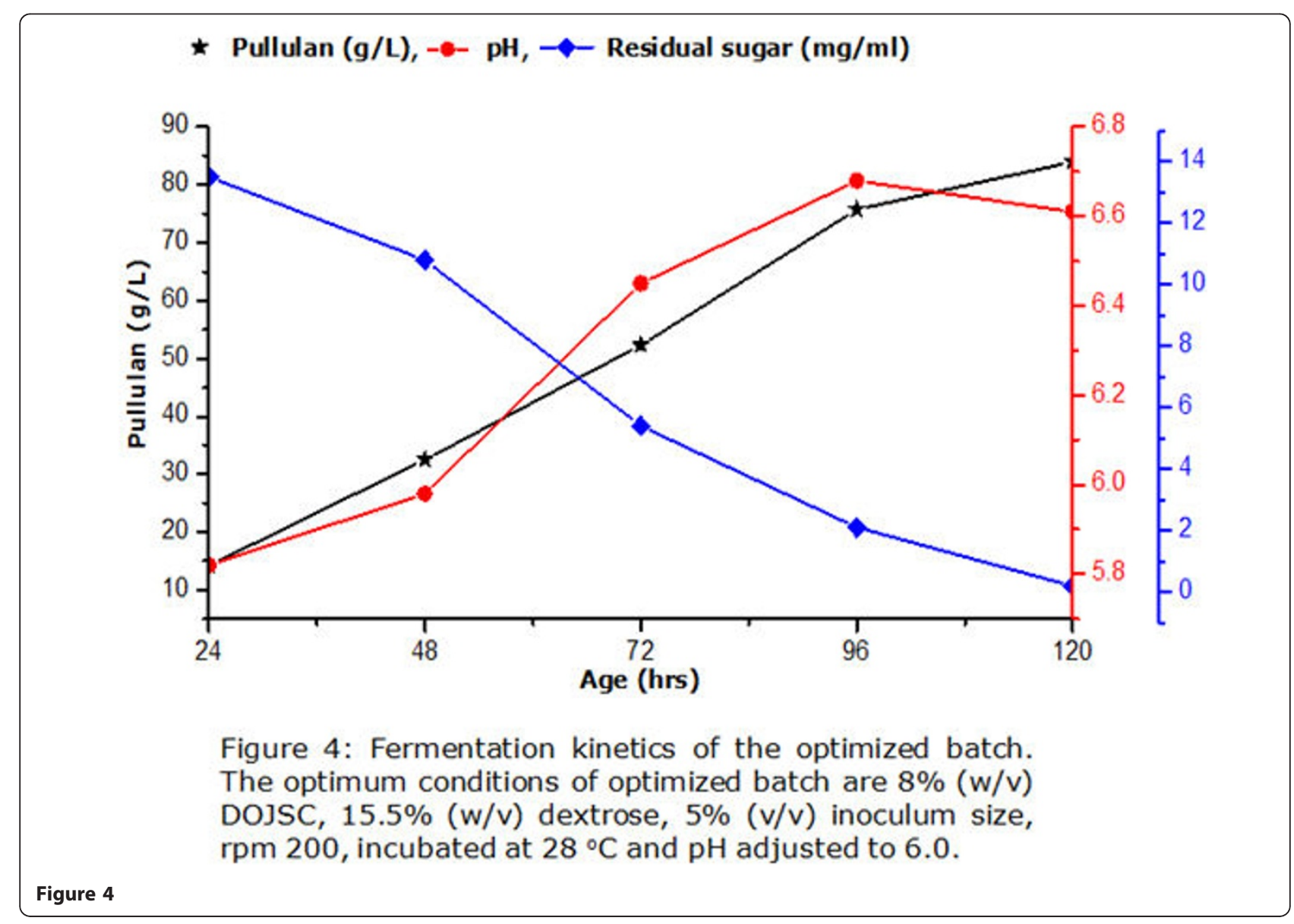


Table 1 Pullulan production using different substrates as carbon and nitrogen source

\begin{tabular}{|c|c|c|c|c|c|c|c|c|}
\hline $\begin{array}{l}\text { Name of } \\
\text { microorganism }\end{array}$ & Substrat & & $\begin{array}{l}\text { Fermentation } \\
\text { Mode }\end{array}$ & $\begin{array}{l}\text { Fermentation } \\
\text { Volume }\end{array}$ & $\begin{array}{l}\text { Pullulan } \\
\text { production }(\mathrm{g} / \mathrm{L})\end{array}$ & $\begin{array}{l}\text { Productivity of } \\
\text { Pullulan } \\
\text { (g/L.h) }\end{array}$ & $\begin{array}{l}\text { Yields of } \\
\text { Pullulan }\end{array}$ & References \\
\hline & $\begin{array}{l}\text { Carbon } \\
\text { source }\end{array}$ & $\begin{array}{l}\text { Nitrogen } \\
\text { source }\end{array}$ & & & & & $\begin{array}{l}\text { g } \\
\text { pullulan/g } \\
\text { sugar } \\
\text { consumed) }\end{array}$ & \\
\hline $\begin{array}{l}\text { Aureobasidium } \\
\text { pullulans }\end{array}$ & Glucose & $\begin{array}{l}\text { Yeast extract, } \\
\text { Peptone }\end{array}$ & Batch & $50 \mathrm{ml}$ & 66.8 & 0.7 & 0.5 & {$[8]$} \\
\hline $\begin{array}{l}\text { Aureobasidium } \\
\text { pullulans }\end{array}$ & Glucose & $\begin{array}{l}\text { Soyabean } \\
\text { pomace }\end{array}$ & Batch & $100 \mathrm{ml}$ & 7.6 & 0.1 & 0.4 & [15] \\
\hline $\begin{array}{l}\text { Aureobasidium } \\
\text { pullulans }\end{array}$ & Sucrose & Beet molasses & Batch & $100 \mathrm{ml}$ & 32 & 0.3 & 0.5 & {$[27]$} \\
\hline $\begin{array}{l}\text { Aureobasidium } \\
\text { pullulans }\end{array}$ & Jaggery & Yeast extract & Batch & $50 \mathrm{ml}$ & 51.9 & 0.7 & 0.5 & {$[28]$} \\
\hline $\begin{array}{l}\text { Aureobasidium } \\
\text { pullulans }\end{array}$ & Glucose & $\begin{array}{l}\text { Ammonium } \\
\text { sulphate }\end{array}$ & Continuous & $800 \mathrm{ml}$ & 3.6 & 0.4 & 0.4 & [29] \\
\hline $\begin{array}{l}\text { Aureobasidium } \\
\text { pullulans }\end{array}$ & Sucrose & $\begin{array}{l}\text { Ammonium } \\
\text { sulphate }\end{array}$ & Continuous & $1.5 \mathrm{~L}$ & 23.1 & 0.9 & 0.6 & {$[30]$} \\
\hline $\begin{array}{l}\text { Aureobasidium } \\
\text { pullulans }\end{array}$ & Sucrose & Beet molasses & Batch & $5 \mathrm{~L}$ & 35 & 0.3 & 0.7 & {$[31]$} \\
\hline $\begin{array}{l}\text { Aureobasidium } \\
\text { pullulans }\end{array}$ & Glucose & DOJSC & Batch & $3.5 \mathrm{~L}$ & 83.9 & 0.7 & 0.7 & $\begin{array}{l}\text { Current } \\
\text { study }\end{array}$ \\
\hline
\end{tabular}

published reports. Successful use of jatropha oil seed cake as nutrient will help in finding a potential application for this toxic by product of biodiesel industry and also have a significant impact on cost reduction of pullulan production process. It is also to be noted that use of DOJSC as substrate will also help in the process economics for biodiesel produced from jatropha. Thus this will have an advantage of helping both biodiesel and chemical/biochemical industry in terms of waste utilization and cost reduction respectively. In conclusion, the present study suggests a novel utilization for the DOJSC and may be helpful in development of a low cost process for pullulan production. Further studies on process scale up using DOJSC as nutrient are under progress.

\section{Materials and methods}

\section{Materials}

The media components were procured from Hi Media Laboratories (Mumbai, India). Pullulan was purchased from Sigma (St. Louis, USA, Cat. No: P4516:). The deoiled jatropha seed cake was kindly provided by Dr. Sunil Khare, Indian Institute of Technology (IIT), Delhi, India. It was obtained in bulk $(3 \mathrm{Kg})$, one lot,

Table 2 Process Economic analysis for raw material cost calculation for production of pullulan using DOJSC

\begin{tabular}{|c|c|c|c|c|c|c|c|c|c|c|}
\hline \multirow{2}{*}{$\begin{array}{l}\text { Raw } \\
\text { material }\end{array}$} & \multicolumn{5}{|c|}{ Process I } & \multicolumn{5}{|c|}{ Process II } \\
\hline & $\begin{array}{l}\text { Requirement } \\
\text { (g/L media) }\end{array}$ & $\begin{array}{l}\text { Rate } \\
(\$ / K g)\end{array}$ & $\begin{array}{l}\text { Cost } / L \\
\text { media } \\
(\$)\end{array}$ & $\begin{array}{l}\text { Pullulan } \\
\text { produced } \\
\text { g/L }\end{array}$ & $\begin{array}{l}\text { Cost of raw } \\
\text { material/Kg } \\
\text { Pullulan } \\
\text { produced } \\
\text { (\$) }\end{array}$ & $\begin{array}{l}\text { Requirement } \\
\text { (g/L media) }\end{array}$ & $\begin{array}{l}\text { Rate } \\
(\$ / K g)\end{array}$ & $\begin{array}{l}\text { Cost } / L \\
\text { media } \\
(\$)\end{array}$ & $\begin{array}{l}\text { Pullulan } \\
\text { produced } \\
\text { (g/L) }\end{array}$ & $\begin{array}{l}\text { Cost of raw } \\
\text { material/Kg } \\
\text { Pullulan } \\
\text { produced }(\$)\end{array}$ \\
\hline Glucose & 150 & 0.8 & 0.1 & 66.8 & 1.8 & 150 & 0.8 & 0.1 & 83.13 & 1.4 \\
\hline $\begin{array}{l}\text { Yeast } \\
\text { Extract }\end{array}$ & 15 & 70 & 1.1 & & 15.7 & - & & & & \\
\hline Peptone & 20 & 28 & 0.6 & & 8.4 & - & & & & \\
\hline DOJSC & - & & & & - & 80 & 0.1 & 0.01 & & 0.1 \\
\hline Total & & & & & 25.9 & & & & & 1.5 \\
\hline
\end{tabular}

*The prices were obtained as per the rate of supply of commercial grade bulk materials by Hi-Media, India (1 USD = 50 INR).

Process I: Roy Choudhury et.al [8]

Process II: Present study 
after production cycle from Biodiesel Production Facility, Centre for Rural Development, IIT-Delhi, India.

\section{Yeast strain and culture conditions}

The yeast strain Aureobasidium pullulans RBF 4A3 was isolated from in florescence of Caseulia axillaries from places near by Rawatbhata, Rajasthan, India, [8]. The culture was maintained in yeast extract, peptone, dextrose (YPD) agar media (Hi Media, India, Cat. No: MI 363 ) at $28^{\circ} \mathrm{C}$ and for long term preservation, $10 \%$ glycerol vials were stored at $-70^{\circ} \mathrm{C}$.

The inoculum was developed by inoculating cultures from fresh YPD agar plates to a $25 \mathrm{ml}$ flask containing $5 \mathrm{ml}$ media composed of $1 \%$ yeast extract (Hi Media, India, Cat. No: RM 027), 2\% peptone (Hi Media, India, Cat. No: CR 001) and 2\% dextrose (Merck, Cat.No: 61780905001730 ) with subsequent incubation at $28^{\circ} \mathrm{C}$ for 24 hours at 200 agitation speed. $2.5 \mathrm{ml}$ of the inoculum developed was used to inoculate $50 \mathrm{ml}$ of production media consisting of de-oiled jatropha seed cake (DOJSC) and dextrose in a $250 \mathrm{ml}$ conical flask. The culture flasks were incubated at $28^{\circ} \mathrm{C}$ and $200 \mathrm{rpm}$ for 120 hours (unless stated otherwise). All the experiments were carried out in triplicate and average values of the results obtained is shown.

\section{Optimization of culture conditions in shake flask}

Single point optimization technique was used to optimize the pullulan production in shake flask level. Factors that have significant effect on pullulan production include concentration of DOJSC, temperature of incubation, agitation speed, inoculum size and initial $\mathrm{pH}$ were varied one at a time to obtain optimum conditions. The optimum conditions obtained from each experiment was used in subsequent experiments unless stated otherwise. All the experiments were carried out in triplicate and average of them are reported.

\section{Effect of concentration of de-oiled seed cake of jatropha in production media}

The concentration of DOJSC was varied in the range of $2 \%(\mathrm{w} / \mathrm{v})$ to $14 \%(\mathrm{w} / \mathrm{v})$ in the production media and the dextrose concentration was maintained at $15 \%(\mathrm{w} / \mathrm{v})$ in all cases. The shake flasks were incubated at $28^{\circ} \mathrm{C}$ and $200 \mathrm{rpm}$. Samples were withdrawn periodically (at every 24 hour interval) and analyzed for pullulan production, residual sugar content and $\mathrm{pH}$.

\section{Effect of temperature on pullulan production}

The temperature of incubation was varied from $15^{\circ} \mathrm{C}$ to $30^{\circ} \mathrm{C}$. The production media was made of $8 \%$ DOJSC and $15 \%$ dextrose. All other process conditions were maintained same as mentioned earlier.

\section{Effect of agitation speed}

In the present study, agitation speed was varied from 100 to 350 . The flasks were incubated at $28^{\circ} \mathrm{C}$ and all other conditions remain unchanged.

\section{Effect of inoculum size}

The effect of inoculum size was studied by varying the same from $2 \%$ to $10 \%(\mathrm{v} / \mathrm{v})$ level. The shake flasks were incubated at $200 \mathrm{rpm}$ and all other conditions were maintained same as earlier.

\section{Effect of initial $\mathrm{pH}$}

The initial $\mathrm{pH}$ of the medium was varied from 3.5 to 6.5 to study the effect of the same on EPS production. In all cases $5 \%(\mathrm{v} / \mathrm{v})$ inoculum was used for inoculating the production media and the samples were withdrawn every 24 hours and analyzed for polymer production.

\section{Analysis, purification and characterization of pullulan}

The fermentation broth was centrifuged at $16,000 \mathrm{~g}$ for $20 \mathrm{~min}$ at $4^{\circ} \mathrm{C}$ using a Sigma $6 \mathrm{~K}-15$ centrifuge to make it cell free. This cell free broth was subjected to solvent precipitation using 2 volumes of ethanol at $4^{\circ}$ $\mathrm{C}$. The precipitate thus obtained was once again separated by centrifugation at $16000 \mathrm{~g}$ for $20 \mathrm{~min}$ at $4^{\circ} \mathrm{C}$. This precipitate was dried at $80^{\circ} \mathrm{C}$ till constant weight. The pullulan content in the exopolysaccharide was determined by enzymatic method [8]. The pullulan content was expressed in terms of gms of pullulan (dry weight) produced per liter of fermentation broth. The residual sugar content was measured by the Miller's method [32] using a Hitachi U-2900 UV-visible spectrophotometer.

\section{Validation of shake flask experiments in a laboratory scale fermenter}

The optimized conditions obtained in shake flask experiments were validated in a $5 \mathrm{~L}$ laboratory scale fermenter (New Brunswick Scientific, Bioflow 310). The production media comprised of $8 \%(\mathrm{w} / \mathrm{v})$ DOJSC and $15 \%(\mathrm{w} / \mathrm{v})$ dextrose and it was inoculated with $5 \%(\mathrm{v} / \mathrm{v})$ inoculum. The fermentation was carried out using 1 vvm air and 350 agitator rpm. The temperature was maintained at $28^{\circ} \mathrm{C}$. The process was continued till 120 hours and samples were withdrawn periodically to analyze pullulan production and residual sugar content.

\section{Additional material}

Additional file 1: Figure S1. FT-IR spectra of standard pullulan (red) and pullulan produced using jatropha as nutrient (black). Absorptions at 3392 $\mathrm{cm}-1$ indicated that both the pullulans have same repeating $-\mathrm{OH}$ units as in sugars. Both the samples resemble similarity in the range 1500-650 $\mathrm{cm}-1$, which is characteristic of pullulan. Absorptions at $848 \mathrm{~cm}-1$ and $750 \mathrm{~cm}-1$ indicate the presence of $\alpha$-D-glucopyranoside units and $\alpha$-(1- 
4)-D-glucosidic linkages respectively, whereas, the absorption at 1126 $\mathrm{cm}-1$ indicate the presence of $\alpha-(1-6)-D$-glucosidic linkages.

\section{Acknowledgements}

The authors acknowledge the financial support obtained from Council of Scientific and Industrial Research, India and also wish to thank Dr. Sunil Khare, IIT-Delhi, India for providing DOJSC used in the experiments.

\section{Author details}

'Biochemical Engineering Research \& Process Development Centre (BERPDC), CSIR-Institute of Microbial Technology (IMTECH), Council of Scientific and Industrial Research (CSIR), Sector - 39A, Chandigarh 160 036, India. ${ }^{2}$ Biochemical Engineering Research \& Process Development Centre (BERPDC), CSIR-Institute of Microbial Technology (IMTECH), Council of Scientific and Industrial Research (CSIR), Sector - 39A, Chandigarh 160 036, India. ${ }^{3}$ Microbial Type Culture Collection and Gene Bank (MTCC), CSIR-Institute of Microbial Technology (IMTECH), Council of Scientific and Industrial Research (CSIR), Sector - 39A, Chandigarh 160 036, India.

\section{Authors' contributions}

Roy Choudhury conceived the study, designed the experimentation and drafted the manuscript. Sharma carried out experiments, provided technical inputs and helped in drafting of the manuscript. Prasad supervised the study and corrected the manuscript. All authors read and approved the final manuscript.

\section{Competing interests}

The authors declare that they have no competing interests.

Received: 22 December 2011 Accepted: 30 March 2012

Published: 30 March 2012

\section{References}

1. Kerr RA: Oil resources. The looming oil crisis could arrive uncomfortably soon. Science 2007, 316:351.

2. Misra RD, Murthy M: Jatropha- The future fuel of India. Renew Sust Energ Rev 2011, 15:1350-1359.

3. Li Z, Lin BL, Zhao X, Sagisaka M, Shibazaki R: System approach for evaluating the potential yield and plantation of Jatropha curcas L. on a global scale. Environ Sci Technol 2010, 44:2204-2209.

4. Sharma DK, Pandey AK: Lata: Use of Jatropha curcas hull biomass for bioactive compost production. Biomass Bioenergy 2009, 33:159-162.

5. Dubois $\mathrm{J}$ : Requirements for the development of a bioeconomy for chemicals. Curr Opin Environ Sustainability 2011, 3:11-14.

6. Abhilash PC, Srivasatav P, Jamil S: Revisited Jatropha curcas as an oil plant of multiple benefits: critical research needs and prospects for the future. Environ Sci Pollut Res 2011, 18:127-131.

7. Ravella SR, Quiñones TS, Retter A, Heiermann M, Amon T, Hobbs PJ: Extracellular polysaccharide (EPS) production by a novel strain of yeastlike fungus Aureobasidium pullulans. Carbohyd Polym 2010, 82:728-732.

8. Choudhury AR, Saluja P, Prasad GS: Pullulan production by an osmotolerant Aureobasidium pullulans RBF-4A3 isolated from flowers of Caesulia axillaries. Carbohyd Polym 2011, 83:1547-1552.

9. Zhao S, Chi Z: A new pullulan producing yeast and medium optimization for its exopolysaccharide production. J Ocean Univ Quingdao 2003, 2:53-57.

10. Leathers TD: Biotechnological production and applications of pullulan. Appl Microbiol Biot 2003, 62:468-473.

11. Lin $Y$, Zhang Z, Thibault J: Aureobasidium pullulans batch cultivations based on a factorial design for improving the production and molecular weight of exopolysaccharides. Process Biochem 2007, 42:820-827.

12. Miller TL, Churchill BW: Substrates for large-scale fermentations. In Manual of Industrial Microbiology and Biotechnology. Edited by: Demain AL, Solomon LA. Washington, DC: American Society for Microbiology; 1986:

13. West TP, Reed-Hamer B: Elevated polysaccharide production by mutants of the fungus Aureobasidium pullulans. FEMS Microbiol Lett 1994 124:167-172
14. West TP, Reed-Hamer B: Ability of Aureobasidium pullulans to synthesize pullulan upon selected sources of carbon and nitrogen. Microbios 1991, 67:117-124.

15. Seo HP, Son CW, Chung CH, Jung D, Kim SK, Gross RA, Kaplan DLL, Lee JW: Production of high molecular weight pullulan by Aureobasidium pullulans HP-2001 with soybean pomace as a nitrogen source. Bioresource Technol 2004, 95:293-299.

16. Ksungur $Y$ : Uzunogulları $P$, Dagbaglı S: Optimization of pullulan production from hydrolysed potato starch waste by response surface methodology. Carbohyd Polym 2011, 83:1330-1337.

17. Shengjun Wu ZJ, Tong Qunyi, Chen Hanqing: Sweet potato: A novel substrate for pullulan production by Aureobasidium pullulans. Carbohyd Polym 2009, 76:645-649.

18. Makkar HPS, Becker K: Potential of J. curcas seed meal as a protein supplement to livestock feed, constraints to its utilization and possible strategies to overcome constraints. In Biofuels and industrial products from Jatropha curcas. Edited by: Gübitz GM, Mittelbach M, Trabi M. Dbv-Verlag Für die Technische Universität Graz, Austria; 1997:190-205.

19. McNeil B, Kristiansen B: Temperature effects on polysaccharide formation by Aureobasidium pullulans in stirred tanks. Enzyme Microbial Technol 1990, 12:521-526.

20. Roukas T, Biliaderis CG: Evaluation of carob pod as a substrate for pullulan production by Aureobasidium pullulans. Appl Biochem Biotech 1995, 55:27-44.

21. Chi Z, Zhao S: Optimization of medium and cultivation conditions for pullulan production by a new pullulan -producing yeast strain. Enzyme Microb Tech 2003, 33:206-211.

22. Vinroot S, Torzilli AP: Interactive effects of inoculum density, agitation and $\mathrm{pH}$ on dimorphism in a salt marsh isolate of Aureobasidium pullulans. Mycologia 1988, 80:376-381

23. Kashyap P, Sabu A, Pandey A, Szakacs G, Soccol CR: Extracellular Lglutaminase production by Zygosaccharomyces rouxii under solid-state fermentation. Process Biochem 2002, 38:307-312.

24. Krishna C: Solid-state fermentation systems-an overview. Crit Rev Biotechnol 2005, 25:1-30.

25. Auer DP, Seviour RJ: Influence of varying nitrogen sources on polysaccharide production by Aureobasidium pullulans in batch culture. Appl Microbiol Biot 1990, 32:637-644.

26. Wang Y, McNeil B: Scleroglucan. Crit Rev Biotechnol 1996, 16:185-215.

27. Roukas T: Pretreatment of beet molasses to increase pullulan production. Process Biochem 1998, 33:805-810.

28. Vijayendra SVN, Bansal D, Prasad MS, Nand K: Jaggery: a novel substrate for pullulan production by Aureobasidium pullulans CFR-77. Process Biochem 2001, 37:359-364.

29. Reeslev M, Jsrgensen BB, Jmgensenb OB: Exopolysaccharide production and morphology of Aureobasidium pullulans grown in continuous cultivation with varying ammonium-glucose ratio in the growth medium. J Biotechnol 1996, 51:131-135.

30. Cheng KC, Demirci A, Catchmark JM: Continuous pullulan fermentation in a biofilm reactor. Appl Microbiol Biotechnol 2011, 90:921-927.

31. Ksungur YG, Ven UG: Production of Pullulan from beet molasses and synthetic Medium by Aureobasidium pullulans. Turk J Biol 2004, 28:23-30.

32. Miller LG: Use of dinitrosalicylic acid reagent for determination of reducing sugar. Anal Chem 1959, 31:426-428.

doi:10.1186/1475-2859-11-39

Cite this article as: Choudhury et al: Deoiledjatropha seed cake is a useful nutrient for pullulan production. Microbial Cell Factories 2012 11:39. 